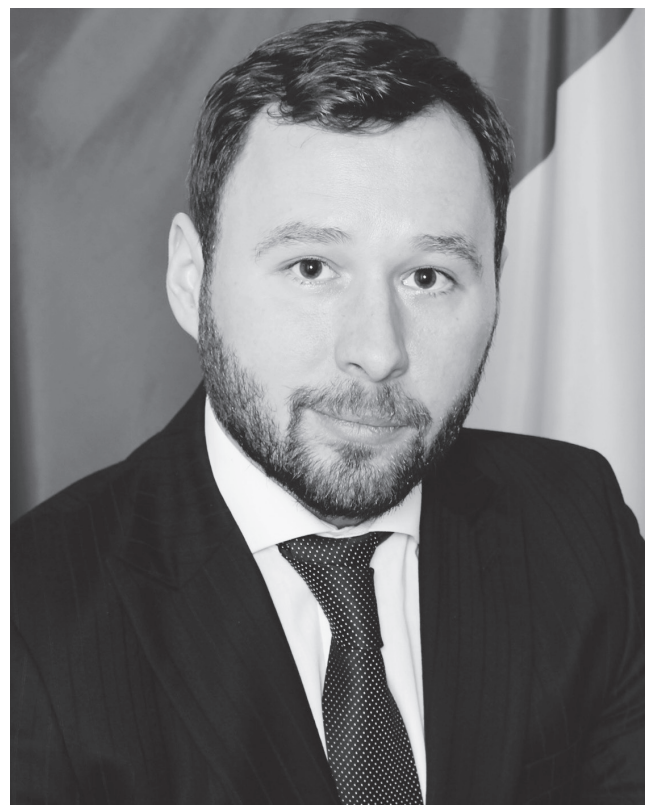

\section{УДК 354}

https://doi.org/10.32689/2617-22242020-5(25)-182-195

Палагусинець Ростислав Васильович, кандидат економічних наук, заступник керівника відділу Управління забезпечення міжпарламентських зв'язків Апарату Верховної ради України, 01008, м. Київ, вул. Грушевського, 5, тел.: (044) 255-3083, e-mail: palarost@gmail.com, https:// orcid.org/0000-0003-1399-7164

\section{Палагусинеи, Ростислав Васильевич,} кандидат экономических наук, заместитель руководителя отдела Управления обеспечения межпарламентских связей Аппарата Верховной Рады Украины, 01008, г. Киев, ул. Грушевского, 5, тел.: (044) 255-30-83, e-mail: palarost@gmail. com, https://orcid.org/0000-0003-13997164

Palagusynets Rostyslav Vasyliovych,

Candidate of Economic Sciences, Deputy Head of the Department of ensuring inter-parliamentary relations of the Verkhovna Rada of Ukraine, 01008, Kyiv, Str. Hrushevskogo, 5, tel.: (044) 255-30-83, e-mail: palarost@gmail.com, https://orcid.org/0000-0003-1399-7164

\title{
ПРІОРИТЕТИ РОЗВИТКУ ТА ЗАХИСТУ ІНТЕЛЕКТУАЛЬНОГО КАПІТАЛУ ДИПЛОМАТИЧНОї СЛУЖБИ
}

Анотація. Розглядаються основні аспекти, пов’язані з характеристикою та аналізом пріоритетів розвитку та захисту інтелектуального капіталу дипломатичної служби в Україні. Проаналізовано основні тлумачення зарубіжних вчених щодо поняття інтелектуального капіталу та його основних складових, у тому числі в контексті інтелектуального капіталу дипломатичної служби. Детально зазначено пояснення кожної складової інтелектуального капіталу та зроблено висновок, що незважаючи на розбіжності в понятті інтелектуального капіталу, зарубіжні вчені ідентично оцінюють роль та значення цієї складової в роботі, в тому числі і дипломатичної служби. Визначено, що людський капітал займає основну частину інтелектуального капіталу дипломатичної служби в Україні. Проведено аналіз зарубіжного досвіду щодо законодавчого забезпечення роботи дипломатичної служби в країнах Європейського Союзу, зокрема в Литві та Болгарії. Обгрунтовано, що використо- 
вуючи моделі та підходи зарубіжних країн Європейського Союзу, як приклади, можна збудувати якісну законодавчу базу в Україні, яка буде стосуватися зокрема інтелектуального капіталу та його ролі в роботі дипломатичної служби. Детально проаналізовано нормативно-правову базу щодо захисту інтелектуального капіталу в Україні, виокремлено основні форми захисту прав інтелектуального капіталу, надано детальну характеристику кожної з даних форм та порядку дій у випадку порушення права на інтелектуальний капітал державних службовців, зокрема дипломатичних працівників Міністерства закордонних справ України. Окремо проілюстровано, що кількість бюджетних працівників дипломатичної служби не планується збільшуватися в найближчі 2 роки (до 2022 року включно). На основі проведеного аналізу та характеристики інтелектуального капіталу дипломатичної служби зроблено висновок, що Закону України “Про дипломатичну службу” № 7322 потребує певних доопрацювань, зокрема до нього мають бути включені чіткі правила, які забезпечують захист інтелектуальної власності дипломатичної служби в Україні, беручи до уваги практику деяких країн Європейського Союзу.

Ключові слова: інтелектуальний капітал, дипломатична служба України, Європейський Союз, Міністерство закордонних справ України, захист інтелектуального капіталу, інтелектуальний капітал дипломатичної служби.

\section{ПРИОРИТЕТЫ РАЗВИТИЯ И ЗАЩИТЫ ИНТЕЛЛЕКТУАЛЬНОГО КАПИТАЛА ДИПЛОМАТИЧЕСКОЙ СЛУЖБЫ}

Аннотация. Рассматриваются основные аспекты, связанные с характеристикой и анализом приоритетов развития и защиты интеллектуального капитала дипломатической службы в Украине. Проанализированы основные толкования зарубежных ученых относительно понятия интеллектуального капитала и его основных составляющих, в том числе в контексте интеллектуального капитала дипломатической службы. Подробно указано объяснение каждой составляющей интеллектуального капитала и сделан вывод, что несмотря на разногласия в понятии интеллектуального капитала, зарубежные ученые идентично оценивают роль и значение этой составляющей в работе, в том числе и дипломатической службы. Определено, что человеческий капитал занимает основную часть интеллектуального капитала дипломатической службы в Украине. Проведен анализ зарубежного опыта законодательного обеспечения работы дипломатической службы в странах Европейского Союза, в частности в Литве и Болгарии. Обосновано, что используя модели и подходы зарубежных стран Европейского Союза, в качестве примеров, можно построить качественную законодательную базу в Украине, которая будет касаться в частности интеллектуального капитала и его роли в работе дипломатической службы. Детально проанализировано нормативно-правовую базу по защите интеллектуального капитала в Украине, выделены основные формы защиты прав интеллектуального капитала, предоставлено подробную характеристику каждой из данных форм и порядка действий в случае нарушения 
права на интеллектуальный капитал государственных служащих, в частности дипломатических работников Министерства иностранных дел Украины. Отдельно проиллюстрировано, что количество бюджетных работников дипломатической службы не планируется увеличиваться в ближайшие 2 года (до 2022 года включительно). На основе проведенного анализа и характеристики интеллектуального капитала дипломатической службы, сделан вывод, что Закон Украины “О дипломатической службе” № 7322 требует определенных доработок, в частности в него должны быть включены четкие правила, которые обеспечивают защиту интеллектуальной собственности дипломатической службы в Украине, учитывая практику некоторых стран Европейского Союза.

Ключевые слова: интеллектуальный капитал, дипломатическая служба Украины, Европейский Союз, Министерство иностранных дел Украины, защита интеллектуального капитала, интеллектуальный капитал дипломатической службы.

\section{PRIORITIES FOR THE DEVELOPMENT AND PROTECTION INTELLECTUAL CAPITAL OF THE DIPLOMATIC SERVICE}

Abstract. The article deals with the main aspects related to the characteristics and analysis of the development and protection priorities of the intellectual capital of the diplomatic service in Ukraine. The main interpretations of foreign scientists regarding the concept of intellectual capital and its main components are analyzed, including in the context of the intellectual capital of the diplomatic service. An explanation of each component of intellectual capital is given in detail and it is concluded that despite the disagreements in the concept of intellectual capital, foreign scientists equally assess the role and importance of this component in the work, including the diplomatic service. It is determined that human capital occupies the bulk of the intellectual capital of the diplomatic service in Ukraine. The analysis of foreign experience of legislative support for the work of the diplomatic service in the countries of the European Union, in particular in Lithuania and Bulgaria. It is substantiated that using the models and approaches of foreign countries of the European Union, as examples, it is possible to build a high-quality legislative framework in Ukraine, in particular, it will concern intellectual capital and its role in the work of the diplomatic service. The regulatory framework for the protection of intellectual capital in Ukraine is analyzed in detail, the main forms of protection of intellectual capital rights are highlighted, a detailed description of each of these forms and procedures is provided in case of violation of the intellectual capital rights of civil servants, in particular diplomatic employees of the Ministry of Foreign Affairs of Ukraine. It is separately illustrated that the number of budget employees of the diplomatic service is not planned to increase in the next 2 years (until 2022 inclusive). Based on the analysis and characteristics of the intellectual capital of the diplomatic service, it was concluded that Law № 7322 "On the diplomatic service" requires certain improvements, in particular, the law should include clear rules that ensure the protection of intellectual pro- 
perty of the diplomatic service in Ukraine, taking into account the practice of some countries of the European Union.

Keywords: intellectual capital, diplomatic service of Ukraine, European Union, Ministry of Foreign Affairs of Ukraine, protection of intellectual capital, intellectual capital of diplomatic service.

Постановка проблеми. Інтелектуальний капітал дипломатичної служби в Україні є дуже значимим, оскільки всі напрацювання, бачення та результати роботи дипломатичної служби відіграють одну із ключових ролей в міжнародній політиці, зокрема міжнародній політиці Європейського Союзу. Механізми захисту інтелектуального капіталу відіграють значну роль у процесі роботи дипломатичної служби. Тому дуже важливо мати правове підгрунтя такого захисту, яке розроблене та ухвалене на найвищому, державному рівні. На превеликий жаль, Україна не демонструє значного покращення у сфері захисту прав інтелектуальної власності, при цьому державні органи подають поганий приклад у контексті дотримання законодавства у цій сфері. Саме недотримання законодавства збільшує ризики щодо унеможливлення повного захисту інтелектуального капіталу дипломатичної служби в Україні і саме мінімізація цього ризику є основним пріоритетом розвитку та, власне, захист інтелектуального капіталу дипломатичної служби України.

Аналіз останніх досліджень і публікацій. Темі характеристики та аналізу основних пріоритетів розвитку та захисту інтелектуального капіталу дипломатичної служби присвячена велика кількість наукових публікацій. Значну увагу дослідженню питань, пов'язаних 3 інтелектуальним капіталом, зокрема його захистом у дипломатичній службі, приділили такі зарубіжні вчені: Е. Брукінг, Д. Даффі, К.-Е. Свейбі, Л. Мелоун, Л. Едвінссон, Д. Лонг, П. Рей, Дж. Гелбрейт та ін. Серед вітчизняних науковців дослідженню цієї проблематики присвячені роботи таких науковців, як С. М. Ілляшенко, Т. Полтавець, С. В. Захарін, М. А. Байков, А. А. Казарян, В. П. Семиноженко, Л. Г. Мельник, А. А. Чухно, В. М. Геєць та ін.

Незважаючи на численні та вагомі дослідження, не всі аспекти цієї актуальної теми з'ясовано та достатньо обгрунтовано.

Мета статті. Характеристика та аналіз пріоритетів розвитку та захисту інтелектуального капіталу дипломатичної служби.

Виклад основного матеріалу дослідження. Поява поняття інтелектуального капіталу практично збігається 3 початком створення та розбудови новітньої економіки, де основним ресурсом є саме знання, здатні створювати інтелектуальний капітал. Інтелектуалізація державних органів, зокрема дипломатичної служби України, стає дедалі об'єктивнішим процесом розширення умов використання інтелектуальних можливостей працівників, надаючи 
праці інтелектуально-інноваційного характеру, що в кінцевому підсумку забезпечує виконання завдань пришвидшення розвитку та захисту інтелектуальної думки.

Незважаючи на відсутність єдиної спільної думки про визначення елементів інтелектуального капіталу, переважна більшість зарубіжних науковців і практиків сходяться на тому, що інтелектуальний капітал $€$ системою певних складових, сукупністю взаємозв'язаних та взаємодоповнюючих елементів. Зрозуміло, що складові інтелектуального капіталу неоднорідні внаслідок неоднорідності самого знання. Незважаючи на те, що всі вони породжені людським інтелектом, одні з них існують у вигляді знань, невіддільних від індивідуумів, які ними володіють, а от інші утворюють, прямо кажучи, умови застосування цих знань для підвищення продуктивності праці та розвитку дипломатичної служби в Україні [1].

Враховуючи той факт, що знання є неоднорідними, елементи інтелектуального капіталу мають свою класифікацію. Наприкінці минулого століття К.-Е. Свейбі розробив розгалуджену структуру інтелектуального капіталу, визначивши його - нематеріальним активом. Перш за все слід відзначити, що автор відносить до інтелектуального капіталу три компоненти, а саме [2]:

1) індивідуальну компетентність (людський капітал);

2) внутрішню структуру інституції;

3) зовнішню структуру інституції.

Дане дослідження зумовило подальші спроби систематизації чинників та елементів, що створюють інтелектуальний капітал. Наприклад, переважно всі дослідники погодилися зі схемою К.-Е. Свейбі, що включає крім людського капіталу, також ще і зовнішні та внутрішні інтелектуальні чинники інституцій. Прикладом може виступати структура інтелектуального капіталу, запропонована Е. Брукінгом та Е. Мотта [3].

Автори визнають суперечність концепції інтелектуального капіталу з бухгалтерськими методами, які традиційно використовуються відносно розрахунків нематеріальних активів. До інтелектуального капіталу інституцій дослідники відносять ринкові активи, активи інтелектуальної власності та інфраструктури, людський капітал (рис. 1).

Активи ринку - це нематеріальні активи дипломатичної служби, що визначають їі положення на ринку

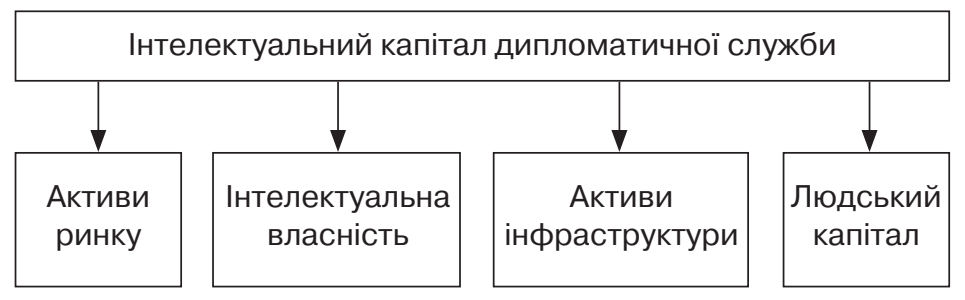

Рис. 1. Структура інтелектуального капіталу компанії (Е. Брукінг, Е. Мотта) Джерело: [2]. 
(Міністерство закордонних справ України, різного роду сприятливі угоди і контракти).

Активи інтелектуальної власності визначаються як інтелектуальна власність, що належить дипломатичній службі при Міністерстві закордонних справ України і захищається законом (патенти, закони, авторські права).

Активи інфраструктури є інтелектуальними активами, які сприяють функціонуванню дипломатичної служби при Міністерстві закордонних справ України (філософія управління, корпоративна культура, процеси управління та ін.).

Людські активи (людський капітал) - це використовувані дипломатичною службою при Міністерстві закордонних справ України знання та вміння, які належать службовцям, починаючи від рядових аналітиків Міністерства закордонних справ України, закінчуючи радниками, що беруть безпосередню участь у переговорах та власне Міністром закордонних справ України [4].

У більш систематизованому вигляді схема інтелектуального капіталу дана Л. Едвінссоном та М. Ме- лоуном. В інтелектуальному капіталі вони чітко розмежовують дві головні складові: людський капітал і структурний капітал, чітко визначаючи при цьому їх зміст (рис. 2).

Перший елемент втілений у самих державних службовцях дипломатичної служби при Міністерстві закордонних справ України та їх колективах у вигляді знань, досвіду, навичок, конкурентних властивостей, здібностей до нововведень, а також у культурі державного управління та внутрішніх цінностях.

Людський капітал, за Л. Едвінссоном, - сукупність знань, практичних навичок і творчих здібностей службовців дипломатичної служби при Міністерстві закордонних справ України, прикладених до виконання поточних задач. Інші його складові - культура праці й загальний підхід до справи та моральні цінності. Людський капітал - це сукупна величина інвестицій у навчання, здібності службовця [2].

На нашу думку, головною складовою інтелектуального капіталу є людський капітал - сукупність знань, навичок, умінь та здібностей. Саме ця складова інтелектуального

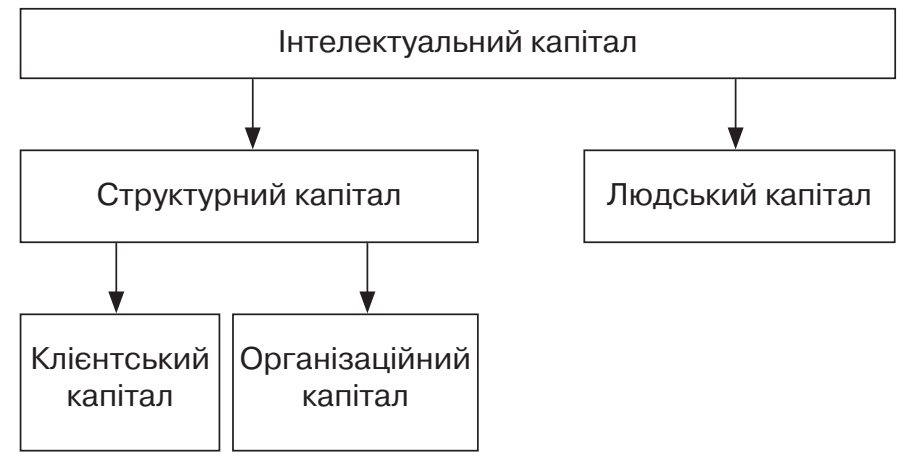

Рис. 2. Структура інтелектуального капіталу (Л. Едвінссон, М. Мелоун) Джерело: [2]. 
капіталу займає найбільшу частку в дипломатичній службі при Міністерстві закордонних справ України. Ця група знань, які мають у своєму розпорядженні працівники, може бути продемонстрована, але їі важко виділити. Передача таких знань може здійснюватися шляхом демонстрації або навчання на робочому місці, при проведенні зустрічей, переговорів. Такі знання важко захистити. Одного разу передавши їх, власник не зможе контролювати використання цих знань. Людські ресурси - найбільш активна і динамічна компонента інтелектуальних можливостей, є основою всіх складових інтелектуального капіталу [2].

У сучасних умовах неймовірно зростає роль високоосвіченої людської особистості, здатної не тільки сприймати раніше накопичене наукове знання, але й узагальнювати, аналізувати, створювати нові знання з подальшим їх використанням у безпосередній роботі дипломатичної служби при Міністерстві закордонних справ України.

Дипломатична служба України створена за умов пострадянського періоду та зберегла деякі чинники дипломатії, що була до 1990 р., особливо, прямолінійність системи такого управління; часткове блокування інформації в обігу і її рівень захисту, який є незадовільним; незначний зв'язок МЗС та дипломатичної служби зі службами при державному управлінні; а також проблеми фінансів та кадрів. Реформа дипломатичної служби та законодавче регулювання великої кількості запитань, що пов’язані з професійною діяльністю державних службовців, є особливо вагомою та непохитною складовою теперішньої державної політики в Україні. [5].

Верхована Рада України 5 квітня 2018 р. прийняла Закон "Про дипломатичну службу” № 7322 [6]. За цей Закон проголосувало парламентська більшість депутатів. Регулювання даного Закону, з точки зору права, відбувається на основі правових норм Віденської конвенції (1961р.) про дипломатичні зносини, Віденської конвенції (1963р.) про консульські зносини, Конституції України та інших актів. Закон "Про дипломатичну службу” містить 10 розділів, перехідних та заключних положень. Вагомим недоліком, на нашу думку, є саме те, що в ньому не міститься обгрунтування щодо розвитку та, особливо, захисту інтелектуального капіталу дипломатичної служби в Україні.

Такі закони беруться за основу в переважній більшості країн Європи, де відповідно орієнтиром є саме положення та основні принципи Віденської конвенції 1961 р. Дана конвенція є відкритою для підпису з боку всіх держав-учасниць Статуту Міжнародного Суду, всіх держав-членів OОH, а також держав, що запрошені Генеральною Асамблеєю ООН бути учасниками Конвенції. Таких держав, загалом, є 179.

У Віденській конвенції чітко прописані основні правила поведінки та обміну офіційних послів між двома країнами. Ця Конвенція може гарантувати, що всі дипломати беззаперечно виконуватимуть обов'язки, покладені на них, без будь-яких загроз впливу уряду країни - приймаючої сторони і вважається основою 
для проведення зовнішніх переговорів та зовнішньої співпраці. Також відповідно до Конвенції дипломати мають чітко дотримуватися всіх законодавчих норм країни, яка виступає як приймаюча, і у разі, якщо буде виявлено певне порушення щодо такого дотримання, можлива негайна депортація дипломати з приймаючої країни. У тому випадку, якщо в Конвенції не вказано відповіді на конкретну дипломатичну проблему, слід використовувати основне право [5].

Віденська конвенція займає вагоме місце у дипломатичній службі Литви. Посилаючись на Закон Литви "Про дипломатичну службу" від 29.12.1998 р. № VIII-1012, дипломатична служба є беззаперечною складовою всієї державної служби країни, яка підпорядковується Президенту, Сейму та Уряду Литви. У даному Законі мова йде про створення дипломатичної служби та їі правове функціонування, про права та статус сімей дипломатів та можливість отримання соціальних гарантій для них. Фінансуються дипломатичні установи та дипломатичні місії за рахунок державного бюджету Литви. Персонал консульських, державних установ має певний імунітет та бонуси, що вказані у Віденській конвенції про консульські зносини. Відповідно до ст. 18 Закону Литви “Про дипломатичну службу” є ряд встановлених вимог до осіб, які займають та можуть бути обрані на дипломатичну службу. Громадянин, який працює дипломатом, повинен бути не старший 62 років та 6 місяців, але є також і виключення, коли особи і старшого віку можуть працювати дипломатичними представниками Литви певний проміжок часу. Така норма і право погоджується Президентом Литви та Міністром закордонних справ [5].

Зарахування на службу в Литві проходить тільки відповідно до конкурсів (конкурсна основа). Особа, яка хоче претендувати на посаду, обов'язково повинна бути 3 Литви та мати громадянство цієї країни, хорошу репутацію, знати та вільно спілкуватися на, мінімум, двух іноземних мовах, а також мати право на отримання державної, секретної інформації. Ні одна особа, яка є задіяною у корупції, або будь-коли була причетна до вчинення кримінального злочину проти своєї країни чи громадян держави, ніколи не буде мати можливість отримати державне місце в дипломатичній службі Литви. Для дипломатів є випробувальний період, тривалістю 1 рік, хоча даний період може бути зменшений за рішенням Міністра закордонних справ до 3 місяців у разі, якщо дипломат показує хороші результати роботи. Варто зазначити, що дипломати не мають права бути залучені до будь-якої роботи протягом часу перебування на державній службі [7].

Парламент Болгарії, ще у 2007 р. погодив подібний Закон, як у Литві. У Законі говориться, що дипломати обираються за допомогою публічного, відкритого конкурсу. Особи, які є переможцями такого конкурсу, автоматично зараховуються на державну службу, маючи посаду помічника та випробувальний період до 18 місяців. Після одного року роботи новий працівник повинен успішно пройти іспит, за результатами якого отримати вищий дипломатичний ранг аташе. Якщо іспит складений невда- 
ло за першого разу, є можливість повторної його здачі через 6 місяців. Якщо і з другого разу вказаний іспит не був складений успішно - ділові відносини з таким державним службовцем припиняються без додаткових попереджень [5].

Щоб стати дипломатичним службовцем, слід мати наступні якості та відповідати вимогам [5]:

1) бути громадянином Болгарії чи $\mathrm{EC}$;

2) вільно розмовляти мінімум 2 мовами;

3) мати освіту магістра;

4) бути комп’ютерно грамотним;

5) не мати будь-яких хронічних психічних захворюваннь.

Відповідно до ст. 34 дипломатичні службовці мають градацію свого ранку, який надається та показує кар'єрні заслуги та кар'єрний ріст відповідно до самої оцінки виконання працівником своїх державних обов'язків, а також професійного досвіду (в роках, місяцях) на державній службі. Щоб отримати вищий (наступний) дипломатичний ранг, слід пройти стажування на попередньому рангу, яке $\epsilon$ обов'язковим.

Слід вказати, що дипломати не мають права бути залучені до будьякої політичної партії чи організації протягом часу перебування на державній службі [5].

Протягом всієї тривалості періоду дипломатичної служби, державний службовець має також отримувати надбавки чи додаткові премії, які нараховуються окремо від заробітньої плати. Сума надбавок та премій залежить від сім’ї службовця та його положення чи дипломатичного рангу. Дана сума нараховується та затверджується 3 боку Ради Міністрів.

Також, під час служби службовець може додатково отримати компенсацію, що покриває в приймаючій державі оплату за навчання його дітей [5].

У законодавстві України слід виокремити дві основні форми захисту прав та інтелектуального капіталу [8]:

1) юрисдикційну;

2) неюрисдикційну.

Юрисдикційна форма - є дієвою, коли державний службовець надає звернення до державних органів чи суду щодо отримання захисту відносно порушення його прав. Ці органи, у свою чергу, уповноважені вжити всі необхідні заходи, щоб відновити порушені права державного службовця. У рамках даної форми захисту слід також окремо виділити судовий і адміністративний порядки захисту порушених прав інтелектуального капіталу.

За судовим порядком захист прав інтелектуального капіталу та охоронюваних законом інтересів здійснюється судом. Переважна більшість таких спорів розглядається місцевими судами. За згодою учасників, спір між ними може бути переданий на розгляд третейського суду. Спори, які виникають між фізичними особами, розглядаються місцевими судами.

Адміністративна форма - це адміністративний порядок їх захисту. У даному випадку працівник направляє звернення до відповідного державного органу, зокрема до Державного департаменту інтелектуального капіталу Міністерства освіти і науки 
України, або до вищого органу відповідача, який за необхідністю може надати такий захист.

Неюрисдикційна форма захисту прав інтелектуального (зокрема, людського) капіталу передбачає, що державні службовці діють самостійсно, без звернень до суду чи відповідних компетентних державних органів щодо захисту своїх прав інтелектуального капіталу.

Як приклад, може бути відмова щодо здійснення певних дій, які не вказувалися при укладанні ліцензійного договору, або навіть відмова від виконання всіх положень договору загалом.

Визначені засоби щодо самозахисту не мають бути суперечливими до законів України та до будь-яких моральних засад. Більше того, способи провести самозахист повинні бути ідентичні до законодавчих, правових норм, відповідати тим правам, які саме були порушені, а також призводити саме до тих наслідків, які виникли як результат такого порушення. Яким саме способом здійснювати захист, державний службовець вибирає самостійно, що і вказує при укладанні договору та актів цівільного законодавства.

До юрисдикційної форми захисту прав можна віднести [8]:

1) цивільно-правову;

2) кримінально-правову;

3) адміністративно-правову.

Цивільно-правова форма захисту прав інтелектуального капіталу - це, насамперед, прававі та матеріальні заходи, що несуть примусовий характер та передбачені законом. Вони покликані допомагати у здійсненні визнаннь або відновленні порушених прав інтелектуального капіталу, припиненні правопорушення.

Спори, що пов'язані з порушенням прав інтелектуального капіталу в Україні, розглядаються загальними, господарськими та адміністративними судами. Справа в суді порушується на підставі позовної заяви, яка подається в письмовій формі особою, права якої порушено. Як правило, позови до фізичної особи подаються в суд за місцем іiї проживання, а до юридичних осіб - за їхнім місцезнаходженням. Загальними цивільноправовими способами захисту прав, що поширюються також і на захист прав інтелектуальної капіталу, є [8]:

1) обгрунтування прав;

2) обгрунтування правочину недійсним;

3) блокування дії, що порушує права;

4) відновлення порушеного становища;

5) виконання обов'язку, в т. ч. примусово;

6) зміни в правовій формі;

7) припинення правовідношення;

8) відшкодування збитків майнової шкоди;

9) відшкодування немайнової шкоди.

Суд може захистити права інтелектуального капіталу іншим цивільно-правовим способом, що встановлений договором чи законом. Цей перелік доповнений положеннями, які стосуються виключно порушення прав інтелектуального капіталу.

Власнику прав інтелектуального капіталу надається можливість вибору способу захисту порушених прав. Наприклад, він вправі на власний розсуд вимагати або відшкодування 
заподіяних збитків, або стягнення на свою користь доходу, одержаного правопорушником внаслідок правопорушення, або виплати компенсації. Якщо порушено немайнові права інтелектуального капіталу, зокрема, елементів людського капіталу, то така моральна шкода відшкодовується грішми або в інший спосіб [9].

При визначенні розмірів збитків, які мають бути відшкодовані особі, права інтелектуального капіталу якої порушено, а також для відшкодування моральної шкоди суд зобов'язаний виходити із суті правопорушення, майнової і моральної шкоди, завданої особі, яка є власником прав інтелектуального капіталу, а також із можливого доходу, який могла б одержати ця особа [10].

Таким чином, маємо ряд нормативно-правових та законних можливостей захисту інтелектуального капіталу, в тому числі, що стосується і набутого інтелектуального капіталу з боку дипломатичної служби Мi- ністерства закордонних справ України.

Слід зауважити, що людський ресурс дипломатичної служби Мiністерства закордонних справ України, який, як зазначалося раніше, $є$ основоположною складовою інтелектуального капіталу, практично не змінюється з року в рік, більше того, прогнозуються на рівні 2019 р. і надалі (рис. 3).

3 боку Кабінету Міністрів України проводиться робота щодо проекту "Національної стратегії розвитку сфери інтелектуального капіталу в Україні терміном до 2020 року", що в найближчій перспективі дасть можливість підвищувати економічну, правову, інституційну та соціальну базу до рівня Європейського Союзу та дасть змогу повністю використовувати продукти інтелектуального капіталу, в тому числі і в роботі дипломатичної служби України [12].

Наявність Нової національної стратегії підкреслює прагнення

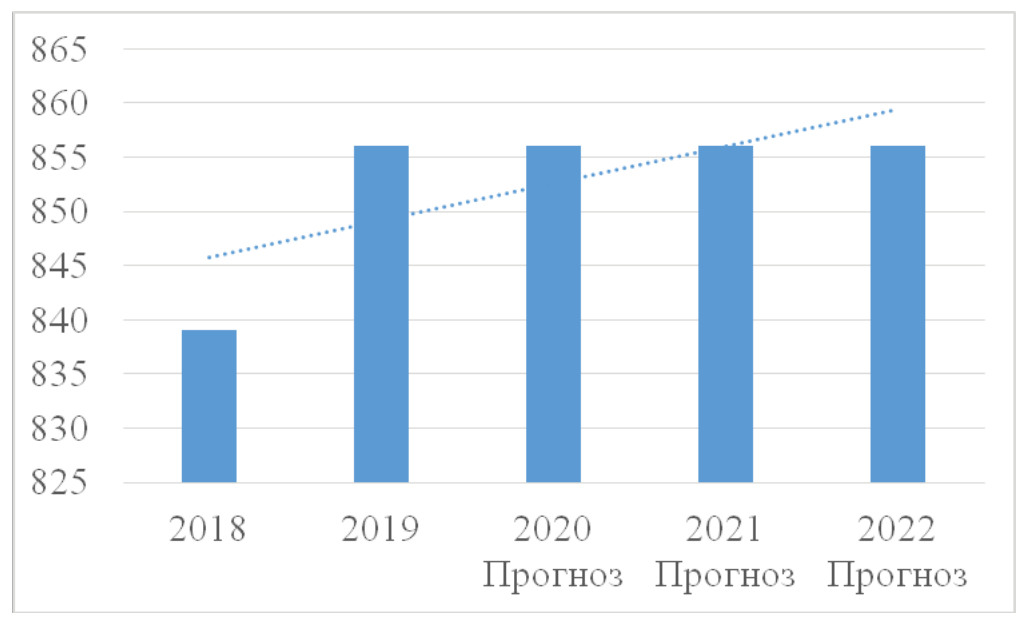

Рис. 3. Динаміка зміни чисельності зайнятих дипломатичних працівників у бюджетних установах

Джерело: [11]. 
України зміцнити інститут інтелектуального капіталу та рухає Україну до правового рівня Європейського Союзу в рамках даного питання. Робота над Національною стратегією розвитку сфери інтелектуального капіталу є безумовним продовженням всього процесу удосконалення цієї сфери інтелектуального капіталу в Україні, що відбувалася в рамках реалізації Концепції розвитку державної системи правової охорони інтелектуального капіталу та спричинено необхідністю вагомих змін, спрямованих на використання інтелектуального капіталу як стратегічного ресурсу підвищення конкурентоспроможності дипломатії України та інтеграції України в Свропейський Союз.

Висновки. На сьогодні інтелектуальний капітал дипломатичної служби Міністерства закордонних справ України є підгрунтям для якісної роботи та врешті решт, виступає як допомога дипломатичній службі, в отриманні необхідного результату для України при переговорах, зустрічах, дискусіях. В Україні діяльність дипломатичної служби регулюється зокрема Законом "Про дипломатичну службу" № 7322. На жаль, цей Закон не містить опису та характеристик, які є пріоритетами розвитку та захисту інтелектуального, зокрема людського капіталу дипломатичної служби України. Тим не менш, в Україні є потужна нормативно-правова база щодо захисту прав інтелектуального капіталу, юридичні ресурси якої дають можливість державному службовцю захищати свої права на людський капітал. Ми вважаємо, що одне з першочерго- вих завдань, при перегляді Закону “Про дипломатичну службу” № 7322 є включення до нього конкретних норм і правил захисту інтелектуального капіталу дипломатичної служби України з різних нормативно-правових документів.

Особливу увагу слід також звернути на практику та досвід із захисту інтелектуального капіталу в країнах Європейського Союзу. Зокрема це стосується Литви та Болгарії. Зарубіжний досвід доводить, що загальноприйняті міжнародні норми імплементовані у національне законодавство без додаткових ускладнень, підтверджують свою ефективність.

\section{СПИСОК ВИКОРИСТАНИХ ДЖЕРЕЛ}

1. Гава Ю. В. Інтелектуальний капітал - шлях до економічного зростання України // Актуальні проблеми економіки. 2006. № 4. С. 129-134.

2. Попело О. В. Інтелектуальний капітал: теоретичний аспект і сучасні тенденції розвитку в Україні // Економіка і регіон. 2015. № 2 (51). C. 66-78.

3. Чухно A. A. Інституціонально-інформаційна економіка: підручник / А. А. Чухно, П. М. Леоненко, П. І. Юхименко / за ред. А. А. Чухна. К.: Знання, 2010. 687 с.

4. Бутко М. П. Інтелектуальний капітал як чинник модернізації регіонального економічного простору : монографія / М. П. Бутко, О. В. Попело; за заг. ред. д-ра екон. наук, проф. М. П. Бутка. Ніжин: ТОВ “Аспект-Поліграф", 2014. 372 с.

5. Полтавець Т. Дипломатична служба в Україні та за кордоном // Громадська думка про правотворення. 2018. № 8 (152). C. 11-14. 
6. Верховна Рада України, ЗУ “Про дипломатичну службу” [Електронний pecypc]. Режим доступу: https:// zakon.rada.gov.ua/laws/show/244919\#Text

7. Малишко О. В. Про європейський формат системи показників вимірювання цінності інтелектуального капіталу регіонального наукового центру // Актуальні проблеми економіки. 2013. № 11. С. 162173.

8. Доріс Лонг. Захист прав інтелектуальної власності: норми міжнародного і національного законодавства та їх правозастосування / Доріс Лонг, Патриція Рей, В. О. Жаров, T. М. Шевелева, I. Е. Василенко, В. С. Дроб'язко // Практичний посіб. К.: К.І.С., 2007. 448 c.

9. Стратегічні виклики XXI століття суспільству та економіці України: у 3 т. / за ред. акад. НАН України В. М. Гейця, акад. НАН України В. П. Семиноженка, чл.-кор. НАН України Б. Є. Кваснюка. К.: Фенікс, 2007. T. 1. C. 194-209.

10. Мамонтова Н. А. Управління вартістю інтелектуального капіталу: теорія і практика // Актуальні проблеми економіки. 2009. № 12. C. $13-18$.

11. Міністерство закордонних справ України "Бюджетний запит на 2020-2022 роки індивідуальний, Форма 2020-2" [Електронний ресурс]. Режим доступу: https://mfa. gov.ua/storage/app/sites/1/budget/ budget2020/forma-2.pdf

12. Стадник O. I. Реалізація угоди про асоціацію між Україною та Свропейським союзом у сфері інтелектуальної власності // Економічні науки. 2016. № 3 (60). С. 206-211.

\section{REFERENCES}

1. Butko M. P., Popelo O. V. (2014), Intelektualny capital yak chinnyk mod- ernizatsii regionalnogo economichnogo prostoru [Intellectual capital as a factor in the modernization of the regional economic space], Kyiv, Ukraine.

2. The Verkhovna Rada of Ukraine (2018), The Law of Ukraine "About the diplomatic service", available at: https://zakon.rada.gov.ua/laws/ show/2449-19\#Text (Accessed 02 of September 2020).

3. Gava U. V. (2006), Intelektualny capital - shliakh do ekonomichnogo zrostannya Ukrainy [Intellectual capital is the way to Ukraine's economic growth], Aktualny problemy economiky, Kyiv, Ukraine.

4. Doris Long P. Rey, Zharov V. O., Sheveleva T. M., Vasylenko I. E., Drobyasko V. C. (2007), Zakhyst prav intelektualny vlasnosty: normy mizhnarodnogo $i$ natsionalnogo zakonodavstva ta ih pravozastosuvannya [Protection of intellectual property rights: norms of international and national legislation and their law enforcement], Kyiv, Ukraine.

5. Malyshko O. V. (2013), Pro evropeyskii format systemy pokaznykiv vumiruvannya tsinnisty intelektualnogo capitalu regionalnogo naukovogo tsentru [On the European format of the system of indicators for measuring the value of intellectual capital of a regional research center], Aktualny problemy economiky, Kyiv, Ukraine.

6. Mamontova N. A. (2009), Upravlinnya vartistu intelektualnogo capital: teoriya i practyca [Intellectual capital value management: theory and practice], Aktualny problemy economiky, Kyiv, Ukraine.

7. Ministry of Foreign Affairs of Ukraine (2020), "Budget request for 20202022, individual, Form 2020-2”, available at: https://mfa.gov.ua/storage/ app/sites/1/budget/budget2020/ forma-2.pdf (Accessed 03 September 2020). 
8. Poltavets T. (2018), Dyplomatychna sluzhba v Ukrainy $i$ za kordonom [Diplomatic service in Ukraine and abroad], Gromadska dumka pro pravotvorennya, Kyiv, Ukraine.

9. Popelo O. V. (2015), Intelektualniy capital: tepretychnyi aspect i suchasny tendentsii rozvytku v Ukrainy [Intellectual capital: theoretical aspect and current trends in Ukraine], Economika i region, Kyiv, Ukraine.

10. Stadnyk O. I. (2016), Realizatsiya ugody pro asotsiatsiu mizh Ukrainou ta Evropeiskym souzom u sferi intelektualnoi vlasnosty [Implementation of the Association Agreement between
Ukraine and the European Union in the field of intellectual property], Ekonomichny nauky, Kyiv, Ukraine.

11. Geets V. M., Semynozhenko V. P., Kvasuk B. E. (2007), Strategichny vyklyky XXI stolitya v suspilstoi ta ekonomitsi Ukrainy [Strategic challenges of the XXI century to the society and economy of Ukraine], Kyiv, Ukraine.

12. Chukhno A. A., Leonenko P. M., Ukhimenko P. I. (2010), Instytutsiinoinformatsiyna ekonomika: pidruchnyk [Institutional and information economics: a textbook], Znannya, Kyiv, Ukraine. 